\title{
The health professional and social media
}

The discussion about what health professionals could post on social networks is a concern that was born along with social media itself. What should be taken into account: common sense, a social relation or a window for professional purpose?

Among physicians, this has been very pervasive; the use of social networks to publicize the kind of professional activity exercised by physician as well as the results and a closer contact among patients has also become popularized among other health professionals such as physiotherapists, occupational therapists and psychologists.

Since health professional achieves his/her training, he/she is charged by the society for an ethical and professional attitude compatible with the current and cultural norms of the present time, however, the world has changed! In the universe of facebook, Instagram, Twitter, Linkedin and Whatsapp, everyone is being watched instantly and the development of the professional image is no longer a privilege for a few scholars, this image is developed through the (pre-) concept of many observers who often are unapt to such development. All these observations sometimes reveal a hasty and incoherent conclusion. It is the price you have to pay for the exaggerated exposure.

Among these networks, Facebook occupies the first position in the most used, representing $83 \%$ in Brazil. Often a client uses the information from these sites in order to define which professional he/she will consult. It is no longer enough for the client to have only technical skills; in the digital scenario, in which we live in, it is also necessary to evaluate personal likings and hobbies, it is a strenuous attempt to identify and share the health professional's lifestyle with his/her own. This search is characterized as an attempt to share tastes and customs. This device, used by patients, is a way to ensure personal narrowing. ${ }^{1}$ This is a dangerous situation not always shared by the user and the creator of the account in the electronic media. In the era of fast and universal internet access, accessing a curricula on academic platforms, or even visiting specific sites, no longer satisfies the clients; they now demand to know about people's personal lives and with the health professionals, this is not different. ${ }^{1}$ The maximum saying "putting on the net is a public domain" has never been so true.

The Regional and Federal Boards are trying to create rules and incorporate them into existing resolutions to coordinate activities online for several professionals. The professional ethics code should serve as a foundation not only for as a control, but above all, guide health professionals as to what they should post or share. ${ }^{2}$

Is the ethics code, for those referred professionals, sufficient to meet this demand? Do you think that perhaps a control is required online? Between 2017 and 2018, the Regional Council on Physiotherapy and Occupational Therapy from the 1st Region (Crefito1), ${ }^{3}$ responsible for Pernambuco, Rio Grande do Norte, Alagoas and Paraíba, has received 210 complaints about the misuse of the networks, 30 of which were for irregular publicity. The organ maintains a specific team to scour websites and social networks two days per week.

As stated by Dr. Paula Moraes from the Universidade Federal de Minas Gerais (Federal University of Minas Gerais), it seems that some caution should always be observed at the moment of posting something, such as ensuring a correct and clear, true and trustworthy writing, confidentiality of the patients and referral copyrights. ${ }^{2}$

Therefore, what should the healthcare professional do to ensure a safe and effective digital activity to maintain respect and guarantee confidentiality when needed? Therefore, it is always good to repeat what has been 
said in countless of times: who promotes oneself takes a risk of self-depreciation.

\section{References}

1. Souza ES, Lorena SB, Ferreira CCG, Amorim AFC, Peter JVS. Ética e Profissionalismo nas Redes Sociais: Comportamentos OnLine de Estudantes de Medicina. Rev Bras Educ Med. 2017; 41 (3): 412-23.

2. Paula Machado. O Profissional de Saúde e as Mídias Sociais. Universidade Federal de Minas Gerais. [acesso em 18 dez 2018]. Disponível em: http://www.infobranding.com.br/profissional-de-saude-e-as-midias/

3. Souza A. Uso das redes sociais por profissionais de saúde deve respeitar limites. Diário de Pernambuco. [acesso em 18 dez 2018 ]. Disponível em: http://www.diariodepernambuco.com.br/app/noticia/vida-urbana/2018/04/29/interna_vidaurbana,750298/uso-dasredes-sociais-deve-respeitar-limites.shtml

\section{Aurélio Antônio Ribeiro da Costa 1 \\ iD https://orcid.org/0000-0002-2641-7686}

${ }^{1}$ Instituto de Medicina Integral Prof. Fernando Figueira. Rua dos Coelhos, 300. Boa Vista. Recife, PE, Brasil. CEP: 50.070-902. 